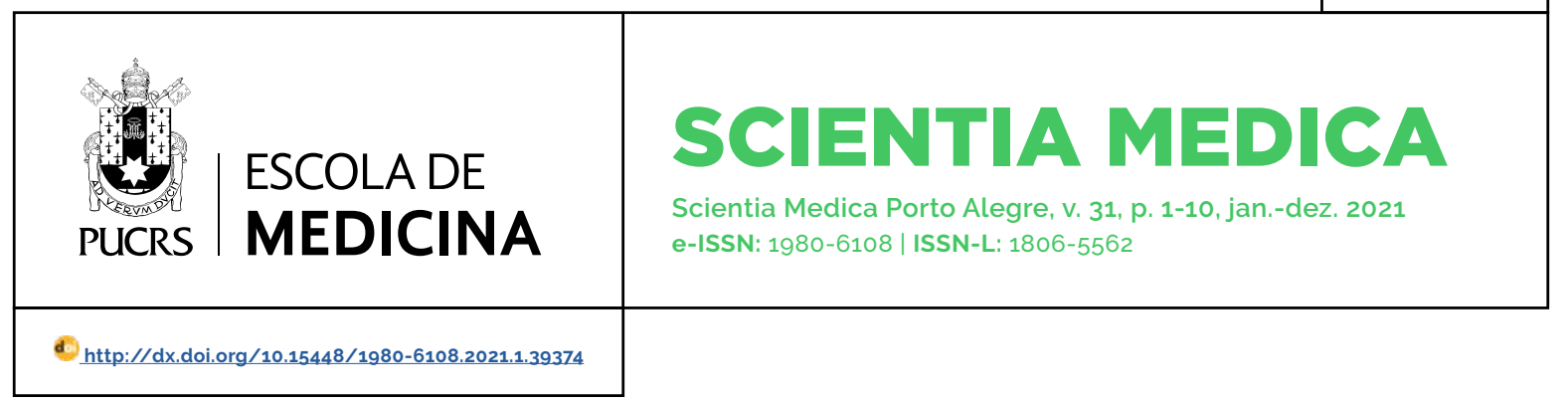

ORIGINAL ARTICLE

\title{
Epidemiology of COVID-19 cases diagnosed at quarantine facilities in Paraguay
}

\author{
Epidemiologia dos casos de COVID-19 diagnosticados nas instalações \\ de quarentena no Paraguai
}

\author{
Pasionaria Rosa Ramos \\ Ruiz Diaz ${ }^{1}$ \\ orcid.org/0000-0002-3684-0912 \\ pasionariaramos@gmail.com \\ Gladys Velázquez ${ }^{2}$ \\ orcid.org/0000-0003-4826-5334 \\ velazquez.aguayo@gmail.com
}

Elder Oliveira da Silva ${ }^{3}$

orcid.org/0000-0002-2298-7497

elder.enf@hotmail.com

\section{Claudia Carolina}

Centurión Viveros ${ }^{4}$

orcid.org/0000-0001-8404-1552

centurion_viveros@hotmail.com

\section{Roberto Esperanza \\ Dullack Peña ${ }^{5}$}

orcid.org/0000-0001-6443-7007

rdullak@gmail.com

\section{Luis Francisco Armoa \\ García $^{5}$ \\ orcid.org/0001-9941-9773 \\ luisarmoa@hotmail.com}

Received on: 16/10/2021 Approved on: 10/02/2021 Published on: 18/02/2021

(c) (1)
Artigo está licenciado sob forma de uma licença
Creative Commons Atribuicão 4.0 Internacional.

\section{ABSTRACT}

Aims: This study aimed to describe the epidemiological characteristics of $\mathrm{CO}$ VID-19 cases diagnosed in quarantine facilities in Paraguay.

Methods: This was a descriptive, cross-sectional, temporarily retrospective study The time scope was from April 1 to September 30 2020. The variables were sex, age and administrative departments. The open access data available on the website of the Ministry of Public Health and Social Welfare was used. Frequencies expressed in percentages and the Chi square value were calculated to observe the statistically significant differences between cases and age and sex.

Results: from April 4 to September 30 2020, 1.581 cases were diagnosed in COVID-19. The fewest number of positive cases were reported in April (50) and the highest number was reported in May (628). From the total, 69.6\% (1.101) were male, (male / female ratio 2.3), 42.1\% (666) were aged between $20-29$ years, the average age was 30.23 years (range o to 87, standard deviation 14.66. 95\% Cl $1.5-58.95$ ). The departments with the highest number of cases were Caaguazú $21.7 \%$ (343), Alto Paraná 17.3 \% (274), Central 13.3\% (210) and Asunción 11.4\% (180). The least number of cases of COVID-10 in women were registered in the Departments of Amambay, Pdte. Hayes, Neembucú and Boquerón, and in men the Departments of Ñeembucú and Boquerón. The largest number of male cases were registered in Caaguazú 70.8\% (243), Alto Paraná 66.1\% (181), Central 69.5\% (146) and Asunción $68.9 \%$ (124). The number of Covid-19 infected people in quarantine facilities presented statistically significant differences between the variables sex and age. Conclusion: the quarantine facilities are one of the measures that the Paraguayan government needed to avoid the rapid spread and dispersion of the virus. The epidemiology of the cases diagnosed in them corresponds to what was expected according to the characteristics of the country.

Key words: Covid-19; epidemiology; shelter; Paraguay

ABREVIATTIONS: MSPBS, Ministry of Public Health and Social Welfare; WHO, World Health Organization

\section{RESUMO}

Objetivo: descrever as caracteristicas epidemiológicas dos casos de COVID-19 diagnosticados em instalações de quarentena no Paraguai.

Metodologia: estudo descritivo, transversal, temporalmente retrospectivo. Quanto ao âmbito temporal foi considerado o periodo de 1 de abril a 31 de setembro de 2020. As variáveis analisadas foram: sexo, idade e Departamentos Administrativos. Foram utilizados dados abertos de acesso público que estão disponiveis na página oficial do Ministério da Saúde Pública e Bem-Estar Social. Foram calculadas frequências expressadas em porcentagem e aplicado o teste de qui-quadrado para ver diferenças estatisticamente significativas entre os casos, idade e sexo.

\footnotetext{
National University of Asuncion. Faculty of Medical Sciences. Department of Epidemiology and Ecology. Asunción, Paraguay

National University of Asuncion. Faculty of Medical Sciences. Department of Microbiology. Asunción, Paraguay

Municipal government. Municipal Secretary of Health of Afua. Afuá, Pará. Brazil

University Sudamericana. Faculty of Medicine. Pedro Juan Caballero, Paraguay

National University of Asuncion. Faculty of Medical Sciences. Asuncion, Paraguay
} 
Resultados: De 4 de abril a 30 de setembro de 2020 , foram diagnosticados 1.581 casos de COVID-19. Em abril houve a menor quantidade de casos positivos (50) e em maio a maior quantidade (628). 69.6\% (1.101) foram em indivíduos do sexo masculino (relação homem/mulher de 2.3). 42.1\% (666) tinham idade compreendida entre 20-29 anos, com uma média de 30.23 anos (classificação o a 87, desvio padrão 14,66, IC 95\% 1.5 - 58.95). Os Departamentos com maior número de casos foram $21.7 \%$ (343), Alto Paraná $17.3 \%$ (274), Central 13.3\% (210) e Assunção 11.4\% (180). O menor número de casos de COVID-19 em mulheres foi registado nos Departamentos de Amambay, Pdte. Hayes, Neembucú e Boquerón, e nos homens, os Departamentos de Ñeembucú e Boquerón. A maior quantidade de casos no sexo masculino foi registrado em Caaguazú 70.8\% (243), Alto Paraná 66.1\% (181), Central 69.5\% (146) e Assunção $68.9 \%$ (124). O número de infectados por COVID-19 nos albergues apresentou diferenças estatisticamente significativas entre as variáveis sexo e idade.

Conclusão: Os abrigos temporários são uma das importantes medidas adotadas pelo governo paraguaio para evitar a rápida dispersão e propagação do virus. A epidemiologia dos casos neles diagnosticados correspondem às esperadas para as caracteristicas do país.

Palavras-chaves: COVID-19, epidemiologia, albergues, Paraguai.

\section{Introduction}

On December 31, 2019, the Chinese health authorities informed the World Health Organization (WHO) about atypical pneumonia cases $(1,2)$. A new coronavirus was identified as Coronavirus 2 (SARS-CoV-2) (3), spreading rapidly around the world (4. 5). On February 11, the WHO called the new disease "COVID-19" $(4,5)$.

Faced with this situation, the countries have taken different types of measures. Thus, for example, China has issued the largest quarantine in history in which all residents were to remain isolated in their homes, closing all types of public transport in the cities (buses, trains, ferries and airports). Due to these measures, COVID-19 cases began to slow down $(6,7)$.

In Europe, the first positive cases were reported in Germany, France, Italy and Spain (7, 8) and preventive measures such as those in Asia were adopted. In addition, special precautions were implemented for suspected or confirmed COVID-19 visits and contacts $(9,10)$. Regarding healthcare professionals, the measures taken were even stricter considering the high risk that they are exposed to $(9,11-13)$.

In South America, the first positive case was reported in Brazil on February 26 (14), while in Paraguay the first positive case reported was on
March 7 (15). As in Europe, the measures in South America were similar, with some particularities for each country. Brazil (16 - 19), Argentina, Uruguay and Paraguay determined quarantine and social distancing measures with different degrees of restrictions, including judicial measures in some cases $(20,21)$.

In Paraguay, when the first diagnosed case was confirmed, the educational and social quarantine was established $(22,23)$, thus breaking the WHO protocol, which establishes the quarantine in the phase 4 of community transmission (24). Other early actions taken by the Paraguayan government were: the suspension of flights from Europe (March 11) (25), declaration of a national health emergency (March 16), the total closure of borders (March 24) $(26,27)$ and declaration of national emergency (March 26) (28). One strategy was the creation of quarantine facilities, declared on the basis of the Decree Number 3526/2020, which authorizes the Ministry of Public Health and Social Welfare (MSPBS) to set up quarantine facilities for supervised isolation of people who have tested positive for COVID-19 in order to cope with the pandemic and prevent its spread in the general population $(20,25)$

The Resolution S.G. Number 166/2020 establishes the situations in which people who have tested positive for COVID-19 must keep supervised isolation in authorized quarantine facilities (26). These situations are for those people who voluntarily wish to get away from their family environment or home; people in a situation of vulnerability who do not have the possibility of isolation at home; people who have violated the required isolation measure; people from coming from foreign countries who are in quarantine in places provided for this purpose and who have tested positive.

Resolution S.G. Number 173/2020 was adhered to the previous one (27), which states that Paraguayans coming from other countries for humanitarian reasons must comply with preventive isolation in a quarantine facility or other place designated for this purpose. However, the measure adopted by the government brought with it many grievances and complaints, not only due to its mandatory nature, but also because of the physical and material infrastructure and services provided by them. 
As defined in the Resolution S.G. Number 228/2020 (28) dated May 31, 2020, a quarantine facility is any physical place that meets the technical requirements established by the MSPBS, for people who need to be in quarantine or isolation. In addition, it defines the criteria and roles of the different levels involved in the operation of the quarantine facilities (27). In this context, the "health hotels" were created for those people who were looking for more comfort during the isolation (14 days). To date, 175 quarantine facilities, 38 health hotels, and 2 health lodging have been set up, assisting 8,000 people (29 - 31). The objective of this study was to describe the epidemiological characteristics of Covid-19 cases diagnosed in quarantine facilities in Paraguay.

\section{Materials and methods}

The study was descriptive, with an analytical, cross-sectional and temporally retrospective component. The geographical area considered for this study was the 18 departments of Paraguay, (including the capital, Asuncion), which corresponds to the political division of the country and which also corresponds to the health divisions

(Figure 1). The time frame considered was from March 7 (the date of the first case diagnosed in the country) until September, 30, since the quarantine facilities stopped working at the end of September approximately $(1,2,3)$.

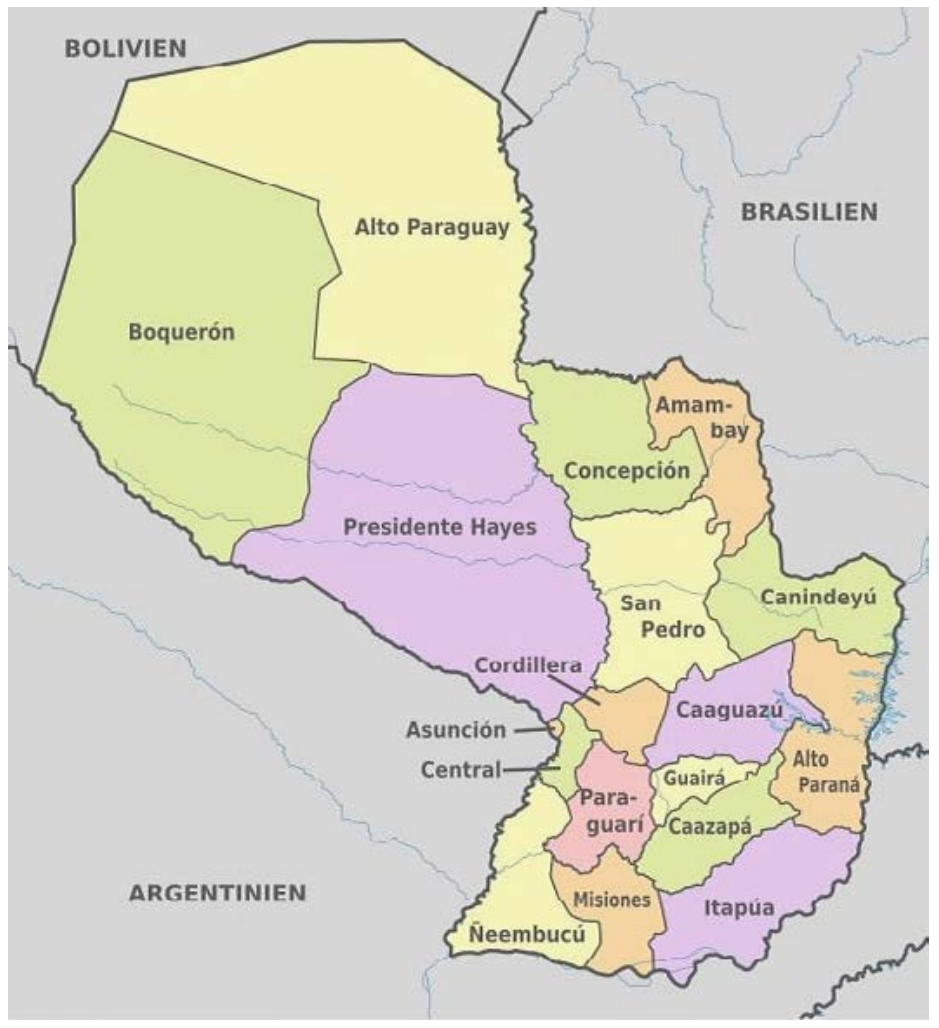

Figure 1 - Political and Health Division of Paraguay (40).

The variables considered were; confirmed cases, sex (male, female), age (average and range) and Departments.

The open access data available on the MSPBS website were used as a data source $(15,32)$.

The statistical analysis of the variables were frequencies expressed as percentages and the Chi-square to analyze the statistically significant differences among variables of COVID-19 cases with respect to age and sex.

Regarding the ethical criteria, since this is a secondary data source research with no participation of human beings, the protocol of this work does not need the approval of the Research Ethics Committee based on Resolution CEP/ CONEP. 510, of April 7, 2016 (33). 


\section{Results}

From April 4 this until September 30, 2020, 1.581 cases of COVID-19 have been diagnosed in the quarantine facilities. The lowest number of positive cases was reported in April, with 50 cases, and the highest number of positive reported cases was May with 628 cases. During this month, the number of cases diagnosed at the quarantine facilities were practically equal to those in the community, since there were 720 cases of community transmission (Figure 2).

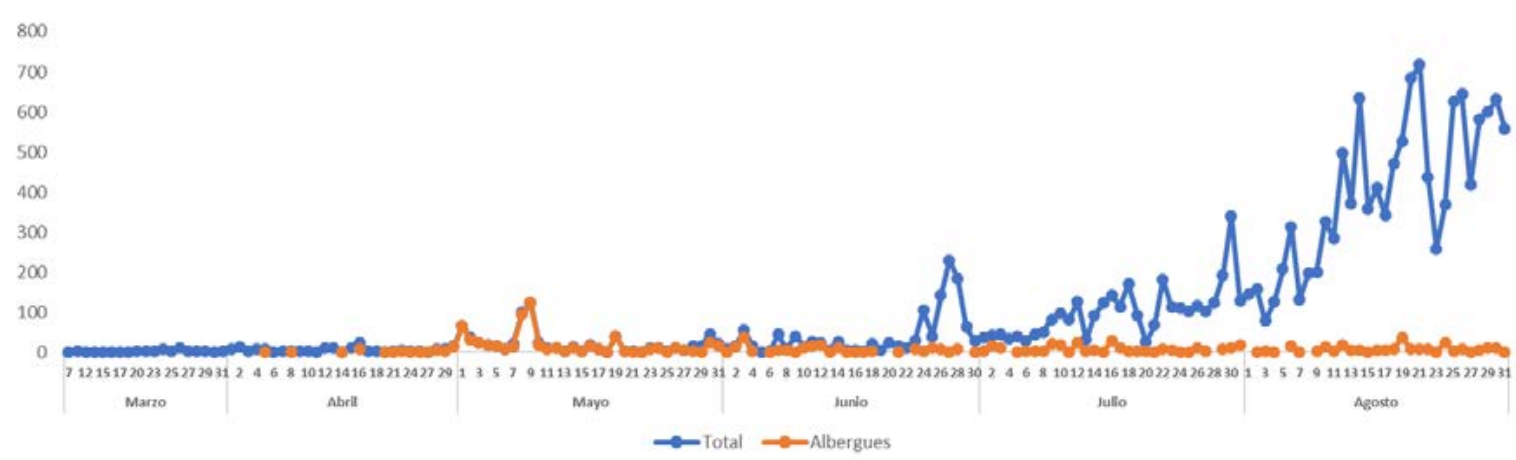

Figure 2 - Distribution of COVID-19 cases diagnosed at quarantine facilities, Paraguay (April - August 2020). Source: Ministry of Public Health and Social Welfare. Paraguay (15).

The male / female ratio was 2.3 of whom $69.6 \%$ (1.101) were male. The mean age was 30.23 years (range 0 to 87 , standard deviation $14.66 .95 \% \mathrm{Cl}$ $1.5-58.95)$. The ages of $42.1 \% \%$ of the cases (666) ranged from 20 to 29 years. Only $0.3 \%$ (4) of the cases were reported in people over 80 years of age. A progressive increase in the average ages was observed throughout the months. In the month of April, the average was 25.1 years, May 24.3 years, June 27.8 years, July 35.3 years, August 37.6 years and September $36.6 \%$ year. $86.7 \%$ of the reported positive cases (1.371) was reported in patients under 50 years of age (Table $\mathbf{1}$ ).

TABLE 1 - Monthly distribution of COVID-19 cases in quarantine facilities, Paraguay (April - September 2020). $N=1.581$

\section{COVID-19 cases in quarantine facilities}

\begin{tabular}{ccc} 
Months & $\mathbf{n}$ & $\%$ \\
\hline April & 50 & 3.2 \\
May & 628 & 39.7 \\
June & 192 & 12.1 \\
July & 256 & 16.2 \\
August & 245 & 15.5 \\
September & 210 & 13.3 \\
\hline
\end{tabular}

Source: Ministry of Public Health and Social Welfare. Paraguay (15).

When relating sex to age, for both sexes, the highest number of cases occurred in the age group 20 to 29 years (Figure $\mathbf{3}$ ). 


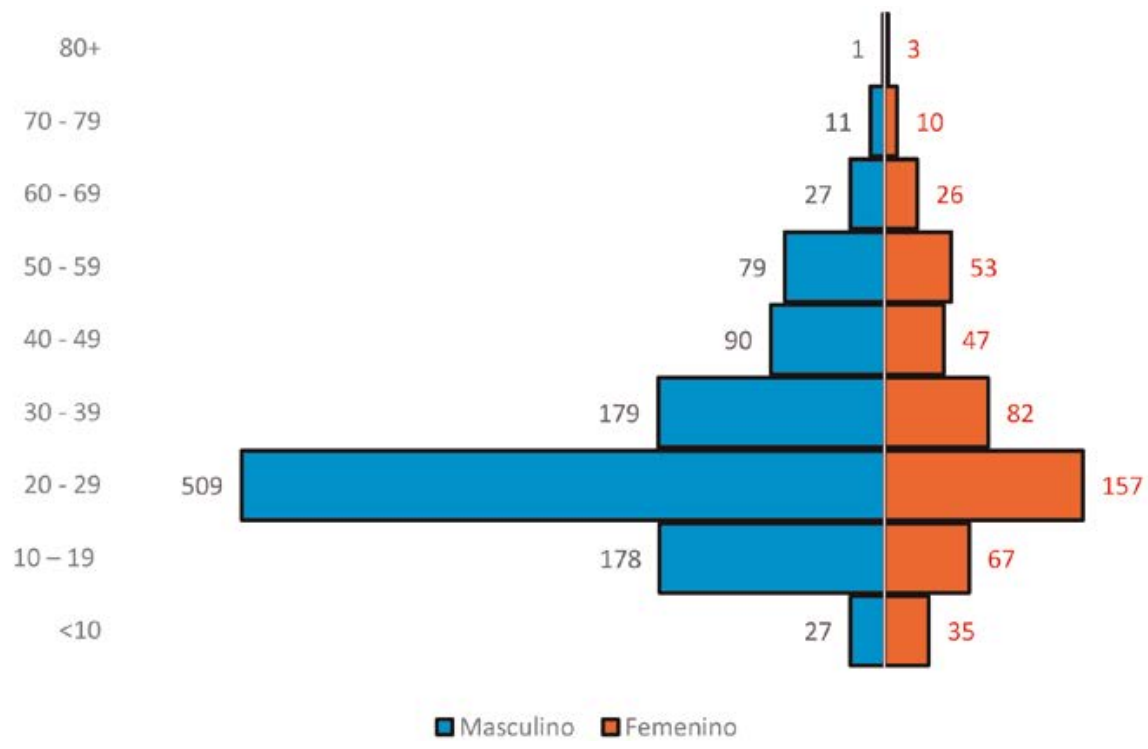

Figure 3 - Pyramid of COVID-19 cases diagnosed at quarantine facilities, Paraguay (April - September 2020). Source: Ministry of Public Health and Social Welfare. Paraguay (15).

Regarding the geographical distribution of the cases according to the Departments, the Departments with the highest percentage of cases were reported in the Departments of were Caaguazú 21.7 \% (343), Alto Paraná 17.3 \% (274), Central 13.3\% (210) and Asunción 11.4\% (180). The least number of cases were registered in patients from the Departments of Amambay, Pdte. Hayes, Ñeembucú and Boquerón (Table 2).

When relating sex to the Departments, $75 \%$ of the female cases were presented in the cases of the Departments of Ñeembucú and $50 \%$ Boquerón. Meanwhile, the highest number of male cases occurred in the Departments of Caaguazú (70.8\%, 243), Alto Paraná (66.1\%, 181), Central (69.5\%, 146) and Asunción $(68.9 \%, 124)$ (Table 3).
TABLE 2 - Geographical distribution of COVID-19 cases in quarantine facilities by Department, $\mathrm{Pa}$ raguay (April - September 2020). N=1.581

\begin{tabular}{|c|c|c|}
\hline Departments & $\mathbf{n}$ & $\%$ \\
\hline Caaguazú & 343 & 21.7 \\
\hline Alto Paraná & 274 & 17.3 \\
\hline Central & 210 & 13.3 \\
\hline Asunción & 180 & 11.4 \\
\hline San Pedro & 143 & 9.0 \\
\hline Itapúa & 113 & 7.1 \\
\hline Cordillera & 56 & 3.5 \\
\hline Guaira & 54 & 3.4 \\
\hline Misiones & 53 & 3.4 \\
\hline Caazapá & 42 & 2.7 \\
\hline Paraguarí & 37 & 2.3 \\
\hline Canindeyú & 33 & 2.1 \\
\hline Concepción & 23 & 1.5 \\
\hline Amambay & 7 & 0.4 \\
\hline Pte. Hayes & 5 & 0.3 \\
\hline Ñeembucú & 4 & 0.3 \\
\hline Boquerón & 4 & 0.3 \\
\hline
\end{tabular}

Source: Ministry of Public Health and Social Welfare. Paraguay (15) 
TABLE 3 - Distribution of COVID-19 cases in quarantine facilities by sex according to Department, Paraguay (April - September 2020).

\begin{tabular}{cccc}
\hline Departments & $\begin{array}{c}\text { Male, } \\
\mathbf{n}(\%)\end{array}$ & $\begin{array}{c}\text { Female, } \\
\mathbf{n}(\%)\end{array}$ & $\begin{array}{c}\text { Total } \\
\mathbf{n}(\%)\end{array}$ \\
\hline Caaguazú & $243(70.8)$ & $100(29.2)$ & $343(100)$ \\
Alto Paraná & $181(66.1)$ & $93(33.9)$ & $274(100)$ \\
Central & $146(69.5)$ & $64(30.5)$ & $210(100)$ \\
Asunción & $124(68.9)$ & $56(31.1)$ & $180(100)$ \\
San Pedro & $91(63.6)$ & $52(36.4)$ & $143(100)$ \\
Itapúa & $81(71.7)$ & $32(28.3)$ & $113(100)$ \\
Cordillera & $43(76.8)$ & $13(23.2)$ & $56(100)$ \\
Guaira & $42(77.8)$ & $12(22.2)$ & $54(100)$ \\
Misiones & $42(79.2)$ & $11(20.8)$ & $53(100)$ \\
Caazapá & $32(76.2)$ & $10(23.8)$ & $42(100)$ \\
Paraguarí & $21(56.8)$ & $16(43.2)$ & $37(100)$ \\
Canindeyú & $26(78.8)$ & $7(21.2)$ & $33(100)$ \\
Concepción & $16(60.6)$ & $7(30.4)$ & $23(100)$ \\
Amambay & $6(85.7)$ & $1(14.3)$ & $7(100)$ \\
Pte. Hayes & $4(80.0)$ & $1(20.0)$ & $5(100)$ \\
Neembucú & $1(25.0)$ & $3(75.0)$ & $4(100)$ \\
Boquerón & $2(50.0)$ & $2(50.0)$ & $4(100)$ \\
Total cases & $\mathbf{1 1 0 1}$ & $\mathbf{4 8 0}$ & $\mathbf{1 . 5 8 1}$ \\
\hline Source & Ministry & & \\
\hline
\end{tabular}

Source: Ministry of Public Health and Social Welfare. Paraguay (15).

Regarding the distribution of cases by sex, according to the different age categories, a high percentage of male patients was observed, except for the extremes of age ( $<10$ and over 70 years) (Table 4$).$
Statistically significant differences were observed when relating the positive reported cases of COVID-19 to age and sex variables.

TABLE 4 - Distribution of COVID-19 cases in quarantine facilities by age categories according to sex, Paraguay (April - September 2020).

\begin{tabular}{cccc}
\hline Age Categories & $\begin{array}{c}\text { Male, } \\
\mathbf{n}(\%)\end{array}$ & $\begin{array}{c}\text { Female, } \\
\mathbf{n}(\%)\end{array}$ & $\begin{array}{c}\text { Total } \\
\mathbf{n}(\%)\end{array}$ \\
\hline$<10$ & $27(43.5)$ & $35(56.5)$ & $62(3.9)$ \\
$10-19$ & $178(72.7)$ & $67(27.3)$ & $245(15.5)$ \\
$20-29$ & $509(76.4)$ & $157(23.6)$ & $666(42.1)$ \\
$30-39$ & $179(68.6)$ & $82(31.4)$ & $261(16.5)$ \\
$40-49$ & $90(65.7)$ & $47(34.3)$ & $137(8.7)$ \\
$50-59$ & $79(59.8)$ & $53(40.2)$ & $132(8.3)$ \\
$60-69$ & $27(50.9)$ & $26(49.1)$ & $53(3.4)$ \\
$70-79$ & $11(52.4)$ & $10(47.6)$ & $21(1.3)$ \\
$>80$ & $1(25.0)$ & $3(75.0)$ & $4(0.3)$ \\
Total cases & $\mathbf{1 1 0}$ & $\mathbf{4 8 0}$ & $\mathbf{1 5 8 1 ( \mathbf { 1 0 0 } )}$ \\
\hline
\end{tabular}

Source: Ministry of Public Health and Social Welfare. Paraguay (2020) (15). 


\section{Discussion}

Paraguay is the country with the lowest number of cases in South America and one of the countries with the lowest number of cases in the world, compared to the United States of America (7,095,422 cases) and Brazil (4,732,309 cases) (34). Presents one of the lowest fatality rates (0.95), compared to countries such as the United Kingdom (15.5), Mexico (12.2), the United States (5.1), and Brazil (3.1) (35). This could be explained by the rapid measures taken by both the national government and the Ministry of Health, being the first to enable quarantine facilities to isolate groups of people and thus avoid the rapid spread of the virus $(22,23,25-29,31)$.

In June the highest number of cases was reported when 231 cases were diagnosed on June 27th. This was due to an outbreak of COVID-19 in the Ciudad del Este prison, where out of the 231 cases, 110 corresponded to inmates (35). Another outbreak of lower proportions of COVID-19 took place in July inside the main prison in Paraguay: the Tacumbú prison in the capital Asuncion (36). Ciudad del Este was the first of the prisons in the country where a COVID-19 positive case was reported, and where the death of a prisoner and two guards was recorded (35). $3.9 \%$ (1.581) of the cases were diagnosed in quarantine facilities, the protocol at first was to carry out the tests at the end of 14th day of quarantine, later the test was performed upon entering the quarantine facilities (37).

Among the reported cases, $69.6 \%$ were male, with a male / female ratio of 2.3. The predominance of males is greater than in countries such as Austria (male / female ratio of 1), Croatia (male/ female ratio of 1.6) or countries (5) such as Italy, France, and Germany where this ratio is 0.95 . The high prevalence of the males can be explained by the fact that men have not complied correctly with the restriction measures due to the economic need to maintain the household and therefore an increasing exposure to the virus (38).

Besides that, $86.7 \%$ of the positive reported cases (1.371) were in those under 50 years of age. These results differ from other countries such as Italy, where the majority of cases occurred in older adults. This would be due to the population pyramid. Paraguay has 1,954,150 young people (ranging from 15 to 29 years), and 486,662 older adults (65 years and above) (39).

According to the geographic distribution, the largest number of positive cases occurred in Caaguazu $21.7 \%$ and the Alto Parana Department $17.3 \%$. This number is justified in the first place to the outbreak that occurred in prison and its subsequent spread. Secondly, the geographical location of the city of Caaguazú in the center of the Eastern Region as well as the proximity to Ciudad del Este which constitutes the largest commercial department in the country and the third largest commercial center in the world lagging behind Miami and Hong Kong. This could explain the large number of positive cases in this location. Asuncion is the capital of the country and it is where the first cases were confirmed, therefore, a greater number of cases is to be expected.

\section{Conclusion}

The quarantine facilities are one of the measures that the Paraguayan government needed to avoid the rapid spread and dispersion of the virus. The epidemiology of the cases diagnosed in them corresponds to what was expected according to the characteristics of the country.

\section{Notes}

Part of this work was presented at Jornadas Iberoamericanas Virtuales Coronavirus y Salud Pública - Lecciones aprendidas de la Covid-19 y retos para los sistemas de salud, (https://WwW. easp.es/web/jornadasiberoamericanascovid/) held during september, 28 -30, 2020, organized by Red Iberoamericana Ministerial de Aprendizaje e Investigación para la Salud (RIMAIS) Institute of Health Carlos III, Madrid, Spain, and Escuela Andaluza de Salud Pública (EASP), Andalucia, Spain.

\section{Funding}

This study did not receive financial support from external sources 


\section{Conflicts of interest disclosure}

The authors declare no competing interests relevant to the content of this study.

\section{Authors' contributions.}

All the authors declare to have made substantial contributions to the conception, or design, or acquisition, or analysis, or interpretation of data; and drafting the work or revising it critically for important intellectual content; and to approve the version to be published.

\section{Availability of data and responsibility for the results}

All the authors declare to have had full access to the available data and they assume full responsibility for the integrity of these results.

\section{REFERENCES}

1. World Health Organization. Emergencies preparedness, response. Pneumonia of unknown cause - China. Disease outbreak news. Geneva: World Health Organization. 2020 Jan 08. [Cited 2020 Jan 07]. Available from: https://www.who.int/csr/don/05-january-2020-pneumonia-of-unkown-cause-china/en/

2. World Health Organization. Statement on the second meeting of the International Health Regulations (2005) Emergency Committee regarding the outbreak of novel coronavirus (2019-nCoV). Geneva: World Health Organization; 2020 Jan 30 [Cited 2020 Feb 02]. Available from: https://www.who.int/news/item/30-01-2020-statement-on-the-second-meeting-of-the-international-health-regulations-(2005)-emergency-committee-regarding-the-outbreak-of-novel-coronavirus-(2019-ncov)

3. Tian H, Liu Y, Li Y, Wu CH, Chen B., Kraemer MU, et al. An investigation of transmission control measures during the first 50 days of the COVID-19 epidemic in China. Science, 2020; 368(6491): 638-42. https://doi. org/10.1126/science.abb6105

4. Salata C, Calistri A, Parolin, C, Palù G. Coronaviruses: a paradigm of new emerging zoonotic diseases. $\mathrm{Pa}$ thog Dis. 2019:77(9):ftaa006. https://doi.org/10.1093/ femspd/ftaaoo6

5. Europe Center Disease Prevention and Control. Weekly surveillance report on COVID-19 [Internet]. Solna: European Centre for Disease Prevention and Control; 2020 Jul 01 [Cited 2020 Jan 07]. Available from: https:// www.ecdc.europa.eu/en/covid-19/surveillance/weekly-surveillance-report
6. Zhai P, Ding Y, Wu X, Long J, Zhong Y, Li Y. The epidemiology, diagnosis and treatment of COVID-19. Int J Antimicrob Agents. 2020;55(5):105955. https://doi. org/10.1016/j.ijantimicag.2020.105955

7. Giovanetti M, Benvenuto D, Angeletti S, Ciccozzi M. The first two cases of 2019 - nCoV in Italy: Where they come from? J Med Virol. 2020;92(5):518-21. https://doi. org/10.1002/jmv.25699

8. Peña-Otero D, Díaz-Pérez D, de-la-Rosa-Carrillo D, Bello-Dronda S. Are you prepared for the new coronavirus? Arch Bronconeumol. 2020:56(4):195-6. https:// doi.org/DOl:10.1016/j.arbres.2020.02.009

9. World Health Organization. Advice on the use of masks in the community during home care and in health care settings in the context of the novel coronavirus (2019-nCoV) outbreak. Interim guidance. Geneva: World Health Organization; 2020 Apr 07 [Cited 2020 Feb 12]. Available from: https://apps.who.int/iris/bitstream/handle/10665/331493/ WHO-2019-nCoV-IPC_Masks-2020.2-eng.pdf

10. Di Tano G, Verde S, Loffi M, De Maria R, Danzi GB Le ricadute della pandemia COVID-19 sulla gestione dell'Ambulatorio Scompenso. Esperienze e considerazioni operative dopo il lockdown. G Ital Cardiol. 2020;21(10):750-56. https://doi.org/10.1714/3431.34197

11. Centers for Disease Control and Prevention (CDC). COVID-19. Interim recommendations for Emergency Medical Services (EMS) systems and 911 public safety answering points (PSAPs) for 2019-n CoV in the United States. Atlanta: Centers for Disease Control and Prevention; 2020 Jul 18 [Cited 2020 Jul 15]. Available from: https://www.cdc.gov/coronavirus/2019-ncov/ hcp/guidance-for-ems.html

12. Gobierno de España. Ministerio de Sanidad. Secretaria de Estado de Sanidad. Dirección General de Salud Pública, Calidad e Innovación. Centro de Coordinación de Alertas y Emergencias Sanitarias. Información Cientíica-Técnica. Nuevo coronavirus 2019-nCoV. Instituto de Salud Carlos III. [Cited 2020 Feb 12]. Available from: https://Www. mscbs.gob.es/profesionales/saludPublica/ccayes/ alertasActual/nCov/documentos/ITCoronavirus.pdf

13. World Health Organization. Infection, prevention and control during health care when novel coronavirus (nCoV) infection is suspected: Interim guidance. Geneva: World Health Organization; 2020 Jan 25 ICited 2020 October 05]. Available from: https://apps.who.int/iris/ handle/10665/330674

14. Brasil. Ministério da Saúde. Secretaria de Vigilância em Saúde. Centro de Operações em Emergências em Saúde Pública - COVID-19. Boletim Epidemiológico 06. Doença pelo Coronavirus. 2020 Apr 03. [Cited 2020 Apr 03]. Available from: https://portalarquivos.saude.gov.br/images/ pdf/2020/April/03/BE6-Boletim-Especial-do-COE.pdf

15. Paraguay. Ministerio de Salud Pública y Bienestar Social. COVID-19: Registro Confirmado [Internet]. Asunción: Ministerio de Salud Pública y Bienestar Social. Direcção Geral de Vigilância Sanitária. 2020 Nov 29 [Cited 2020 Nov 28]. Available from: https://public.tableau.com/profile/mspbs\#!/vizhome/COVID19PY-Registros/Descargardatos 
16. Bastos F, Feal-Zubimendi, S, Hernaiz D, Miller SJ, Queijo von Heideken V, Rossi JL, dt al. Banco Interamericano de Desarollo (BID). Departamento de Países del Cono Sur (CSC). ALC Post COVID-19: Retos y oportunidades para paises del Cono Sur. 2020. http://dx.doi. org/10.18235/0002372

17. Brasil. Ministério da Saúde. Gabinete do Ministro. Portaria MS/GM n 188/2020. Declara Emergência em Saúde Pública de importância Nacional (ESPIN) em decorrência da Infecção Humana pelo novo Coronavírus (2019-nCoV). [Internet] Brasília: Diário Oficial da União, Edição 24-A, Seção 1 - Extra, p.1; 2020 Feb 4 [Cited 2020 Mar 27]; Section 1: 1. Available from: http://www.in.gov.br/web/dou/-/portaria-n-188-de-3-de-fevereiro-de-2020-241408388 18. Croda JHR, Garcia LP. Immediate response to Health Surveillance for the COVID-19 epidemic. Epidemiol SerV Saúde. 2020;29(1):e2020002. https://doi.org/10.5123/ s1679-49742020000100021

19. Center for Disease Control and Prevention (CDC). Implementation of mitigation strategies for communities with local COVID-19 transmission [Internet]. Washington, DC: Center for Disease Control and Prevention; 2019 [cited 2020 Mar 27]. 10 p. Available from: https:// www.cdc.gov/coronavirus/2019-ncov/downloads/ community-mitigation-strategy.pdf

20. Center for Disease Control and Prevention (CDC). Implementation of mitigation strategies for communities with local COVID-19 transmission [Internet]. Washington, DC: Center for Disease Control and Prevention; 2019 [Cited 2020 Mar 27]. 10 p. Available from: https:// www.cdc.gov/coronavirus/2019-ncov/downloads/ community-mitigation-strategy.pdf

21. Markel H, Stern AM, Navarro JA, Michalsen JR, Monto AS, Di Giovanni C. Nonpharmaceutical influenza mitigation strategies, US communities, 1918-1920 pandemic. Emerg Infect Dis. 2006;12(12):1961-4. https:// doi.org/10.3201/eid1212.060506

22. Paraguay. Ministerio de Salud Pública y Bienestar Social. COVID-19: La salud y la vida como bandera IInternet]. Asunción: Ministerio de Salud Publica y Bienestar Social. 2020 Jul 01. Available from: https://www.mspbs. gov.py/portal/21224/covid-19-la-salud-y-la-vida-como-bandera.html

23. Paraguay. Poder Ejecutivo. Ministerio de Salud Publica y Bienestar Social. Resolution S. G. n' 9o. Por la cual se establecen medidas para mitigar la propagación del coronavirus (COVID-19). [Cited 2020 Mar 10]. Available from: https://www.mspbs.gov.py/dependencias/portal/adjunto/5a7857-RESOLUCIONSGgoCOVID19.pdf

24. World Health Organization. Emergencies preparedness, response. What is phase 6?. Geneva: World Health Organization; 2020 Aug 11. [Cited 2020 Jun 11]. Available from: https://Www.who.int/csr/disease/swineflu/frequently_asked_questions/levels_pandemic_alert/en/
25. Paraguay. Ministerio de Salud Pública y Bienestar Social. Decreto n`3526/2020. Por el cual se autoriza al Ministerio de Salud Pública y Bienestar Social a habilitar albergues destinados para el aislamiento supervisado de personas que han dado positivo en los test de corona virus (COVID-19). [Cited 2020 Apr 09]. Available from: https://www.mspbs.gov.py/dependencias/portal/ adjunto/1c4cb9-DECRETO3526.PDF

26. Paraguay. Ministerio de Salud Publica y Bienestar Social. Resolution SG No. 166/2020. Available from: https://www.mspbs.gov.py/dependencias/portal/ adjunto/1c8572-RESOLUCIONSG.N166.pdf

27. Paraguay. Ministerio de Salud Publica y Bienestar Social. Resolution SG No 173/2020. Available from: https://www.mspbs.gov.py/dependencias/portal/ adjunto/5f31c2-ResolucinN173Medidasdestinadasapersonasprovenientesdeotrospases.pdf

28. Paraguay. Ministerio de Salud Pública y Bienestar Social. Resolución S.G. $n^{\circ}$ 228/2020. Por la cual se aprueba un nuevo protocolo de orientación para personas que requieran cumplir cuarentena o aislamiento, evaluación y funcionamiento de albergues, en el marco del estado de emergencia sanitaria declarado por el gobierno de la república en la lucha contra la pandemia de coronavirus (COVID-19); y se abroga la Resolución S.E. $n^{\circ} 212$, de fecha 9 de mayo de 2020. ICited 2020 May 31]. Available from: https://Ww/w.mspbs.gov.py/dependencias/portal/adjunto/82b3a5-RES228DE2020.pdf

29. Rodriguez A. Albergues en Paraguay: la trinchera contra el COVID-19 [Internet]. Buenos Aires: Infobae; $2020 \mathrm{Jul} 03$ [Cited $2020 \mathrm{Jul}$ 03]. Available from: https:// www.infobae.com/america/agencias/2020/07/03/albergues-en-paraguay-la-trinchera-contra-el-covid-19/

30. Paraguay. Secretaria Nacional de Turismo. Instalaciones Hoteleras. Estrategias Hotel Salud. ICited 2020 Sep 15]. Available from: https://Www.senatur.gov.py/ materiales/archivos/0700_15_09_2020.pdf

31. Paraguay. Ministerio de Salud Pública y Bienestar Social. COVID-19: Isolation in quarantine facilities, a key strategy in containing the pandemic [Internet]. [Cited 2020 Jul 31]. Available from: https://www.mspbs.gov.py/portal/21412/covid-19-aislamiento-en-albergues-una-estrategia-clave-en-la-contencion-de-la-pandemia.html

32. Paraguay. Ministerio de Salud Pública y Bienestar Social. COVID-19: Reporte Semanal [Internet]. Asunción: Ministerio de Salud Pública y Bienestar Social. Direcção Geral de Vigilância Sanitária. 2020 Nov 30 [Cited 2020 Nov 30]. Available from: https://public.tableau.com/ profile/mspbs\#!/vizhome/COVID-19PYReporteSemanal/Covid19R_Semanal

33. Universidade Federal do Rio Grande do Norte (UFRN). Comitê de Ética em Pesquisa. Pesquisas que não necessitam de registro no sistema CEP/CONEP Resolução n 510/2016 - CNS. [Cited 2018 Dec 20]. Available from: http://www.cep.propesq.ufrn.br/noticias/ pesquisas-que-nao-necessitam-de-registro-no-sistema-cep-conep-resolucao-no-510-2016-cns/28749886 
34. John Hopkins University and Medicine. Coronavirus Resource Center. Global Map. COVID-19 Dashboard by the Center for Systems Science and Engineering (CSSE) at John Hopkins University (JHU). [Cited 2020 Oct 05]. Available from: https://coronavirus.jhu.edu/map.html

35. Alonso TF. Brote importante de COVID-19 en carcel de Ciudad del Este [Internet]. Asunción: ABC en el Este; 2020 [Cited 2020 Jun 24]. Available from: https://WwW. abc.com.py/nacionales/2020/06/24/brote-importante-de-covid-19-en-carcel-de-ciudad-del-este/

36. Cristaldo A. COVID-19 gets into the Tacumbú prison, the largest and most overcrowded in Paraguay [Internet]. Asunción: EFE Agency. [Cited 2020 Aug 20]. Available from: https://www.efe.com/efe/america/sociedad/el-covid-19-penetra-en-la-carcel-de-tacumbu-mayor-y-mas-hacinada-paraguay/20000013-4307160

37. Paraguay. Ministerio de Salud Publica y Bienestar Social. Ingresados a albergues son sometidos a test de COVID 19. [Cited 2020 May 07]. Available: https://www. mspbs.gov.py/portal/20895/ingresados-a-albergues-son-sometidos-a-test-de-covid-19.html

38. Guerra M. Estudo multidisciplinar liderado pela UFBA identifica bairros de Salvador mais vulneráveis à COVID-19. Edgar Digital. Universidade Federal da Bahia (UFBA). Salvador; [Cited 2020 Apr 02]. Available from: http://www.edgardigital.ufba.br/?p=16356

39. Paraguay. Dirección General de Estadística (DGEE). Encuestas y Censos [sito web]. Paraguay; 2020 May 10. Available from: https://www.dgeec.gov.py/default. php?publicacion $=33$

40. Paraguay. Portal de Información de Paraguay [Internet]. Paraguay: 2020 Oct 29. Available from: https:// paraguay-info.net/das-land/departamentos.html

\section{CORRESPONDENCE}

Claudia Carolina Centurión Viveros

Universidad Sudamericana. 14 de Mayo casi, Pedro Juan Caballero, Paraguai. 